\title{
AC 2008-749: BIOTECHNOLOGY AND BIOPROCESSING AND MICROBIOLOGY LABORATORY COURSES: A MODEL FOR SHARED USE OF INSTRUCTIONAL LABORATORIES BETWEEN ENGINEERING AND SCIENCE
}

\section{Susan Sharfstein, Rensselaer Polytechnic Institute}

Susan Sharfstein is an Assistant Professor in the Departments of Chemical and Biological Engineering and Biology at Rensselaer Polytechnic Institute. Her research interests are in mammalian cell culture for bioprocessing. Her teaching interests are in biotechnology and biochemical engineering and in integrating engineering and life science education. Professor Sharfstein received her Ph.D. in Chemical Engineering from UC Berkeley. She is the recipient of an NSF CAREER award whose educational component focused on undergraduate laboratory development.

\section{Blanca Barquera, Rensselaer Polytechnic Institute}

Blanca Barquera is an Assistant Professor of Biology and Chemistry and Chemical Biology at Rensselaer Polytechnic Institute. Her research interests are in energy transduction in microorganisms, particularly Vibrio cholerae. She received her Ph.D. in biology from the National Autonomous University of Mexico.

\section{Michael Hanna, Rensselaer Polytechnic Institute}

Michael Hanna is an Associate Professor of Biology at Rensselaer Polytechnic Institute. He also serves as Co-Director of the Accelerated Physician/Scientist Program, Associate Dean of Academic Advising, Assessment and Special Programs, Director of the Advising \& Learning Assistance Center, and Chair of the PreHealth Professions Committee. His research interests include slime mold development, in vitro gene evolution, mutagenesis, and protein engineering. He has taught all levels of undergraduate and graduate courses in biology over the past 29 years at RPI. Most recently, he has been involved in curricular design for a novel introductory biology course. Professor Hanna received his Ph.D. in microbiology from the University of Illinois. 


\section{Biotechnology and Bioprocessing and Microbiology Laboratory Courses: A Model for Shared Use of Instructional Laboratories between Engineering and Science}

\section{Introduction}

Laboratory courses are highly resource intensive, both in development and renovation of laboratory space and purchase and maintenance of laboratory equipment. As novel technologies such as biotechnology, nanotechnology, and semiconductor processing enter into engineering research, there is a strong demand to provide exposure to these areas at the undergraduate level in the context of an engineering program rather than in biology, chemistry or physics courses. Ideally, that exposure would include a laboratory component; however, it is often prohibitively expensive to acquire the instrumentation necessary for these courses. Moreover, undergraduate engineering laboratories are often poorly designed for small-scale experiments, having been built to accommodate large pieces of equipment.

In developing a biotechnology and bioprocessing laboratory course for the Department of Chemical and Biological Engineering at Rensselaer Polytechnic Institute, we encountered many of these challenges. Our traditional senior/unit operations laboratory contained a large distillation column, pumping equipment, and a heat exchange experiment with limited bench space for small scale microbiology and molecular biology manipulations. We had received funding from the School of Engineering and the Merck Foundation to purchase equipment; however, the funds were insufficient to purchase all of the desired equipment.

In examining existing teaching laboratories on campus, including chemistry laboratories, a molecular biology laboratory, and a microbiology laboratory, we discovered that the Biology Department had recently renovated laboratory space and purchased new equipment for the microbiology course with a grant from the Howard Hughes Medical Institute. This renovated space contained a number of large pieces of equipment such as shakers and incubators as well as electrophoresis equipment. As only one section of the microbiology course was taught annually, the laboratory was underused. By negotiation between the Department of Chemical and Biological Engineering and the Department of Biology, we were able to share the laboratory space. With funds from the Provost and School of Engineering as well as the funds from the Merck Foundation, we were able to renovate additional preparatory laboratory space, including purchase of a large autoclave and water purification system that was not previously available in the building as well as providing shared equipment such as a teaching microscope and a high speed floor centrifuge.

\section{Description of courses taught}

\section{Biotechnology and Bioprocessing Laboratory}

The Biotechnology and Bioprocessing Laboratory is an optional section of the required senior laboratory in Chemical and Biological Engineering. All students take the traditional laboratory in the fall semester and have the option of taking the traditional lab or the biotechnology lab in the spring semester. The experiments in this course have been designed to represent the process by 
which a biotechnology product is developed and manufactured. Students perform a series of integrated experiments that begin with basic microbiology and then take a product through the entire production process including molecular biology manipulations to insert a gene into a foreign organism, expression of the protein in batch and fermentor culture, protein purification and activity assays. The course culminates with a field trip to a local biotechnology company to see real world applications of the techniques the students have learned. A typical course schedule is shown in Table I. (Sample experiments are given in Appendix A; the entire course manual and teaching manual can be obtained by contacting the first author at sharfs@rpi.edu .) The course consists of a one-hour lecture and a four-hour laboratory every week. As biological systems cannot be forced to conform to this schedule, students are often required to come into the lab either the day before or the day after the primary lab period to set up or check the results of the experiments. The course makes extensive use of an on-line learning management system (Blackboard ${ }^{1}$ ) for supplementary and reference material as well as experimental results (e.g. gel pictures).

Several model proteins have been explored, but currently the protein produced is $\beta$ galactosidase. This is an enzyme that catalyzes the hydrolysis of lactose to glucose and galactose. It is commonly used as a reporter gene in many molecular biology studies so its gene is widely available in a variety of cloning systems. In addition, several artificial substrates for the enzyme exist which yield colored products; hence, there are several relatively easy assays for its presence and activity.

\section{Microbiology}

The microbiology course is a sophomore-level biology course that is offered as an elective course. It consists of two 1.5-hour lectures and one three-hour laboratory weekly. While there is some overlap in the experiments performed between the biotechnology laboratory and the microbiology lab, the focus is much more on basic microbiological techniques with a small amount of recombinant DNA technology covered at the end of the semester. A typical laboratory schedule is shown in Table II.

While the course is nominally a sophomore-level course, it is also taken by upperclassmen, particularly pre-dental and pre-pharmacy students as it is required for admission to those programs. Currently, one laboratory section is offered with a maximum enrollment of 16 students (although a few additional students can often be accommodated); however, due to increased demand, an additional section is being considered for the 2008-2009 academic year. Other possible changes include changing from one three-hour laboratory period to three one-hour laboratory periods to better accommodate the nature of biological experimentation. 
Table I: Schedule of experiments for Biotechnology and Bioprocessing Laboratory

\begin{tabular}{|c|c|c|}
\hline Week & Lecture & Laboratory \\
\hline 1 & & $\begin{array}{l}\text { Introduction, microplate reader } \\
\text { spectrophotometer software demo }\end{array}$ \\
\hline 2 & $\begin{array}{l}\text { Sterile technique. Bacterial } \\
\text { and mammalian cell } \\
\text { morphology }\end{array}$ & $\begin{array}{l}\text { Experiment } 1 \\
\text { Pouring/streaking plates } \\
\text { Cell mass determination } \\
\text { Microscopy } \\
\text { Wet and dry mounts } \\
\text { Trypan blue exclusion }\end{array}$ \\
\hline 3 & $\begin{array}{l}\text { Cloning, PCR, gel } \\
\text { electrophoresis }\end{array}$ & $\begin{array}{l}\text { Experiment } 2 \\
\text { PCR, agarose gel electrophoresis }\end{array}$ \\
\hline 4 & Bacterial transformation & $\begin{array}{l}\text { Experiment } 3 \\
\text { Cloning }\end{array}$ \\
\hline 5 & $\begin{array}{l}\text { Plasmid purification, } \\
\text { restriction enzymes }\end{array}$ & $\begin{array}{l}\text { Experiment } 4 \\
\text { Plasmid purification, restriction digests, } \\
\text { agarose gel electrophoresis }\end{array}$ \\
\hline 6 & $\begin{array}{l}\text { Batch culture } \\
\text { Growth kinetics } \\
\text { Nutrient uptake }\end{array}$ & $\begin{array}{l}\text { Experiment } 5 \\
\text { Bacterial transformation } \\
\text { Batch culture } \\
\text { Induction and activity, nutrient uptake }\end{array}$ \\
\hline $7-8$ & Fermentor & $\begin{array}{l}\text { Experiment } 6 \\
\text { Fermentor run }\end{array}$ \\
\hline 9 & Protein purification & $\begin{array}{l}\text { Experiment } 7 \\
\text { Two-phase aqueous extraction, fraction } \\
\text { assay, protein assay }\end{array}$ \\
\hline 10 & Protein purification II & $\begin{array}{l}\text { Experiment } 8 \\
\text { Column chromatography }\end{array}$ \\
\hline 11 & Analytical techniques & $\begin{array}{l}\text { Experiment } 9 \\
\text { Electrophoresis }\end{array}$ \\
\hline 12 & Enzyme kinetics & $\begin{array}{l}\text { Experiment 10 } \\
\text { Kinetics }\end{array}$ \\
\hline 13 & $\begin{array}{l}\text { Oral and written report } \\
\text { overview }\end{array}$ & Field trip to Regeneron Pharmaceuticals \\
\hline 14 & Oral Reports & Oral Reports \\
\hline
\end{tabular}


Table II: Schedule of experiments for Microbiology lab

\begin{tabular}{|c|l|}
\hline Week & Lab exercise \\
\hline 1 & $\begin{array}{l}\text { Intro to microbiology } \\
\text { Microbe scavenger } \\
\text { Examining bacteria through infusion }\end{array}$ \\
\hline 2 & $\begin{array}{l}\text { What has the most bacteria } \\
\text { Chapter } 8: \text { Swab mouth } \\
\text { Disinfectants and scrubbing }\end{array}$ \\
\hline 3 & $\begin{array}{l}\text { Bacteria study kit. } \\
\text { Gram-staining of bacterial lab investigation }\end{array}$ \\
\hline 4 & $\begin{array}{l}\text { Streak plate method of isolation } \\
\text { Chapter 18. Pure culture. Mix of } \text { E.coli and } \text { Vibrio harveyi }\end{array}$ \\
\hline 5 & Antibiotic effects kit \\
\hline 6 & $\begin{array}{l}\text { Coliform test kit. Triple sugar iron agar (TSI). Carbohydrate } \\
\text { fermentation test }\end{array}$ \\
\hline 7 & Chapter 20. Bacterial population counts \\
\hline 8 & Carbon dioxide production and yeast lab \\
\hline 10 & How viruses travel lab investigation \\
\hline 11 & $\begin{array}{l}\text { Citrate utilization test. } \\
\text { Thioglycolate broth for anaerobic growth } \\
\text { Blood agar test }\end{array}$ \\
\hline 12 & Motility semi-solid medium \\
\hline 13 & DNA preparation. Plasmid DNA \\
\hline 14 & pGLO bacterial transformation kit I \\
\hline
\end{tabular}

\section{Funding mechanisms}

As sufficient funding for laboratory development is often not available from internal resources, both departments obtained significant external funding for both the equipment and renovation. Details of the external funding sources as well as internal resources used are given below.

\section{Howard Hughes Medical Institute (HHMI)}

HHMI, a non-profit medical research organization that ranks as one of the nation's largest philanthropies, plays a powerful role in advancing biomedical research and science education in the U.S. In the past two decades HHMI has made investments of more than $\$ 8.3$ billion for the support, training, and education of the nation's most creative and promising scientists. The Institute commits almost $\$ 700$ million a year for research and distributes $\$ 80$ million in grant support for science education. Founded in 1953 by Howard R. Hughes, the aviator and industrialist, HHMI is headquartered in Chevy Chase, Maryland, and employs more than 2,600 individuals across the U.S. It has an endowment of $\$ 16.3$ billion. $^{2}$

HHMI awards grants to biomedical research institutions, universities, and colleges to support innovative science education programs at the pre-kindergarten to 12th-grade and undergraduate 
levels. These programs seek to encourage young people's interest in science, prepare them for science-related careers, and increase science literacy among all students, including non-science majors. ${ }^{3}$

In 1998, the Department of Biology at Rensselaer Polytechnic Institute, received funding from HHMI for a novel, interdisciplinary program in Bioinformatics and Molecular Biology. As microbiology was seen as an essential component of this proposed program, $\$ 130,000$ from this grant was made available for laboratory renovation and purchase of new equipment to upgrade an existing microbiology laboratory course.

\section{The Merck Company Foundation}

The Merck Company Foundation is a US-based, private charitable foundation. Established in 1957 by Merck \& Co., Inc., the Foundation is funded entirely by the Company and is Merck's chief source of funding support to qualified non-profit, charitable organizations. The mission of the Foundation is to support organizations and innovative programs in alignment with four strategic priorities:

- Improving access to quality health care and the appropriate use of medicines and vaccines

- Building capacity in the biomedical and health sciences

- Promoting environments that support innovation, economic growth and development in an ethical and fair context

- Supporting communities where Merck employees work and live ${ }^{4}$

Within the Merck Foundation, the Engineering Advisory Committee provides support to engineering schools and engineering-related organizations. Areas in engineering education funded by the Engineering Advisory Committee are:

- Graduate and undergraduate engineering education in the areas of chemical engineering including biochemical, mechanical, and industrial systems engineering with primary focus on chemical engineering

- Curriculum and faculty development focusing on needs of pharmaceutical industry

- Programs that foster diversity representation among engineering students and faculty, such as programs to improve retention of minority students

The Chemical and Biological Engineering Department at Rensselaer Polytechnic Institute has an extended relationship with Merck \& Co., Inc., More than 20 students from our department (including those with B.S., M.S., and Ph.D. degrees) are or were employees at Merck. Merck has funded two summer internships for RPI engineering undergraduates annually, with many of those students taking permanent positions at Merck. Faculty from the department have interacted with scientists at the Merck Research Laboratories (including sabbatical leaves), and several active research collaborations are underway. Furthermore, our department has a long and highly 
recognized program in biochemical engineering, with particular emphasis on downstream processing and biocatalysis, both critical components for the pharmaceutical industry. Our historical interactions with Merck, the high percentage of women undergraduates in our program ( $40 \%)$, and the relevance of the proposed Biotechnology and Bioprocessing laboratory to Merck's core businesses made this an attractive proposal to the Merck foundation.

We had previously purchased a 2.5-liter New Brunswick BioFlow 3000 bacterial fermentor and a YSI biochemistry analyzer with funds made available from the Dean of Engineering for ABET related laboratory improvements. In fall 2002, we submitted a proposal to the Engineering Research Council to develop a biotechnology and bioprocessing laboratory, requesting funds for molecular biology equipment, a teaching microscope, chromatography equipment, and a microplate reader spectrophotometer for enzyme kinetics. We felt that a microplate reader was particularly advantageous because it would allow many students to run assays simultaneously and expose them to high throughput approaches that are used commonly in industry. Our proposed budget is shown in Table III. We committed to substantial cost sharing including the cost of an large autoclave (shared by the School of Engineering and the Department), one year of teaching-assistant support provided by the School of Engineering and release time for the PI (the first author of this paper) to develop the laboratory.

\section{Table III: Proposed budget for Merck-supported laboratory in Biotechnology and Bioprocessing}

\begin{tabular}{|l|r|}
\hline Item & Total Cost \\
\hline $\begin{array}{l}\text { Liquid handling/chromatography } \\
\text { equipment (pipetors, mixers, pumps, etc.) }\end{array}$ & $\$ 7,880.00$ \\
\hline Dual viewing compound microscope & $\$ 9,800.00$ \\
\hline Shakers and Incubators & $\$ 8,500.00$ \\
\hline Electrophoresis Equipment & $\$ 1,400.00$ \\
\hline Thermocycler & $\$ 5,000.00$ \\
\hline Gel Documentation System & $\$ 6,200.00$ \\
\hline Microplate Reader/Spectrophotometer & $\$ 25,000.00$ \\
\hline Electroporation System & $\$ 4,000.00$ \\
\hline High speed floor centrifuge & $\$ 30,000.00$ \\
\hline & $\$ 97,780.00$ \\
\hline Total & \\
\hline
\end{tabular}

After review by the Merck Foundation and the Engineering Advisory Council, we were awarded a grant of $\$ 65,000$, in January 2003 with specific instructions that the funds were to be used to purchase the high speed floor centrifuge, the microplate reader spectrophotometer, and the microscope. While this was a substantial gift, it was significantly less than we anticipated would be necessary to equip the laboratory. However, as described below, because of the substantial amount of equipment already available in the Microbiology laboratory, and most importantly, the willingness of the Biology faculty to permit our students to use this instrumentation, we were able to purchase all of the equipment we deemed essential for the laboratory course. 


\section{Internal funding support}

In addition to funds provided by the foundations, the Department of Chemical and Biological Engineering provided $\$ 20,000$ from unrestricted gift funds towards the purchase of a large autoclave; the School of Engineering provided \$20,000, and \$50,000 was provided by the Provost's Office, primarily towards renovating preparative laboratory space for installation of the autoclave. As this laboratory space would benefit two departments, one in the School of Engineering and one in the School of Science, and both departments had generated substantial external funding, we were able to justify a contribution from the Provost's Office to provide the remaining support.

\section{Overview of equipment purchased and space renovation}

\section{Equipment purchased}

\section{Equipment purchased by Biology Department}

With funds provided by HHMI, the Biology Department was able to purchase a number of pieces of equipment, new glassware and small equipment used in a standard microbiology laboratory as well as the renovation described below. Major pieces of equipment purchased included a BioRad gel documentation system, a table-top refrigerated centrifuge, four New Brunswick Scientific BioFlow 110 fermentors, a refrigerator/freezer, two incubators, shaking heating blocks, vertical and horizontal gel electrophoresis equipment, and microcentrifuges. In addition, a number of large shakers were previously available in the laboratory, and these were placed into the environmental rooms, eliminating the need for shaking incubators.

\section{Equipment purchased by Chemical and Biological Engineering Department}

Due to the large amount of equipment that was already available in the microbiology laboratory and the microplate reader costing substantially less than was projected, we were able to purchase majority of the items needed for the laboratory with the funds provided by the Merck Foundation. We decided not to purchase the electroporator, as chemically competent cells can now be obtained in a variety of cloning kits. A breakdown of the equipment purchased for the Biotechnology and Bioprocessing Laboratory is given in Table IV. If shared equipment had not been available, an additional $\$ 20,000$ would have been required to equip the laboratory.

Table IV: Equipment purchased for Biotechnology and Bioprocessing Laboratory

\begin{tabular}{|l|r|}
\hline Item & Total Cost \\
\hline High speed centrifuge & $\$ 28,669$ \\
\hline Centrifuge supplies & $\$ 500$ \\
\hline Microscope & $\$ 11,518$ \\
\hline Microplate reader & $\$ 15,278$ \\
\hline Computer for microscope and plate reader & $\$ 1,695$ \\
\hline Micropipettes & $\$ 3,221$ \\
\hline Thermo-cycler & $\$ 2,732$ \\
\hline Mixers & $\$ 386$ \\
\hline Balances & $\$ 1,350$ \\
\hline
\end{tabular}




\section{Teaching laboratory renovation}

The instructional laboratory is $\sim 100$ square feet as shown in Figure 1. It is located in the Jonsson-Rowland Science Center which was constructed in the 1960s. Prior to the renovation, it had been used as instructional space; however, the conditions were highly unsatisfactory including peeling paint, asbestos flooring, insufficient or poorly functioning cabinetry, poorly functioning environmental rooms, etc. As part of the renovation, each student work space was made computer accessible with hard wired internet connections. The total renovation costs were approximately $\$ 60,000$ and major items are described in Table $\mathrm{V}$.

\section{Table V: Renovation costs for teaching laboratory}

\begin{tabular}{|l|r|}
\hline Item & Approximate cost \\
\hline Building repairs (internal work) & $\$ 5500$ \\
\hline Asbestos testing and abatement & $\$ 6000$ \\
\hline Flooring (epoxy and sand floor) & $\$ 9200$ \\
\hline Carpentry & $\$ 4800$ \\
\hline Cabinetry and casework & $\$ 13,300$ \\
\hline Electrical & $\$ 3900$ \\
\hline Painting & $\$ 9100$ \\
\hline HVAC & $\$ 1800$ \\
\hline
\end{tabular}

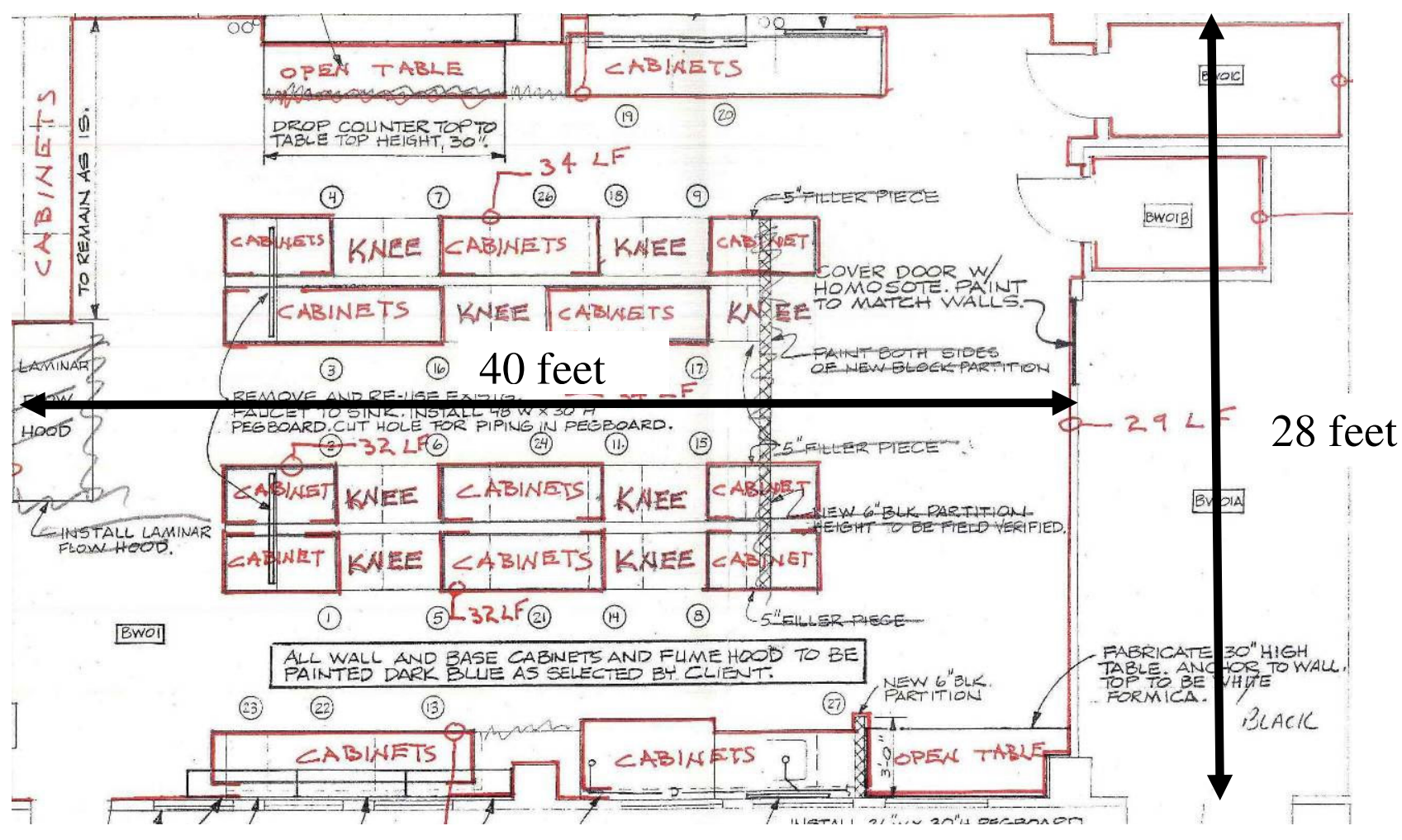

Figure 1: Schematic of teaching laboratory. Environmental rooms are shown on the right. 
The project was initiated in late June 2002, with the goal of having the laboratory space completed in time for the fall semester. Due to the expedited construction schedule, the project was completed in early-mid September, not before the start of the semester, but with enough of the semester remaining that the laboratory was usable for some of the course.

\section{Preparative laboratory renovation}

One of the key purchases for the Biotechnology and Bioprocessing laboratory was a large (>39"'chamber height) autoclave that could easily accommodate a 2-3 liter bioreactor. When we decided to perform the laboratory instruction in the recently renovated teaching laboratory space, one key objective was to locate the autoclave either in the instructional space or in close proximity to the instructional space to reduce the risk of damage to the bioreactor from transporting it long distances on a cart. In evaluating the instructional space, it became clear that there was not adequate space to install the autoclave, and even if space were available, a large, hot autoclave could potentially pose a significant safety risk in a classroom full of students.

A 280-square foot room in close proximity to the instructional lab was identified. This room had previously been used as an autoclave room. It was in substantial disrepair, containing three nonfunctional autoclaves, an old chest freezer, rotting cabinetry, and significant amounts of asbestos.

As we designed the renovation of this space for installation of the autoclave, we observed that there was no reagent grade water $(18 \mathrm{MOhm})$ on this floor of the Science Center, requiring teaching assistants to transport 50-liter jugs of water from other floors. Plans were made to install a water purification system and a glassware washer to reduce the work load of the teaching assistants. The schematic for the complete room is shown in Figure 2. The total renovation costs including the autoclave, deionized water and a polishing system, and the

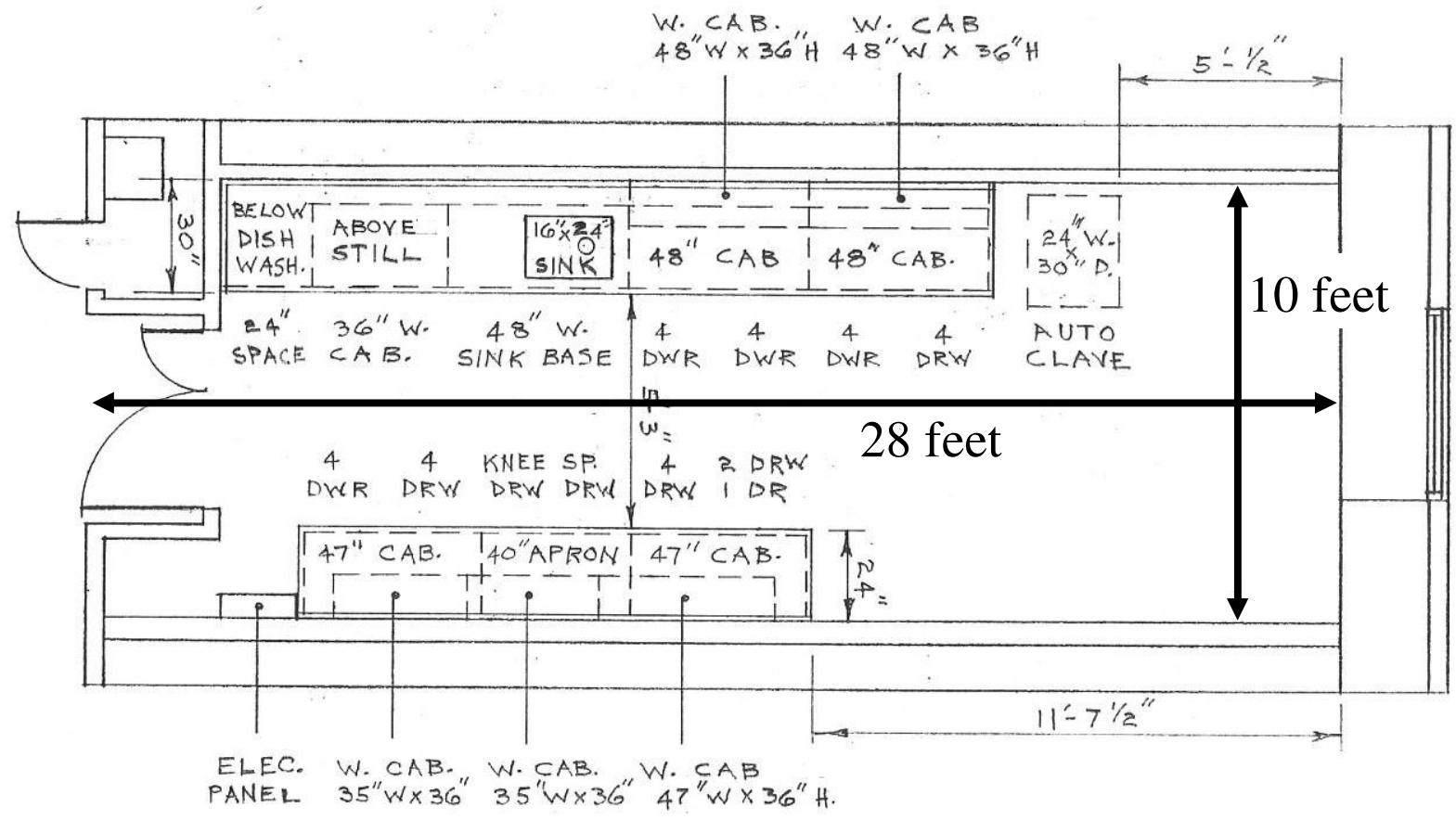

Figure 2: Schematic of the preparatory laboratory 
glassware washer were approximately $\$ 90,000$ and are detailed in Table VI.

Table VI: Renovation costs for preparatory laboratory

\begin{tabular}{|l|r|}
\hline Item & Approximate cost \\
\hline Removal of old chemicals & $\$ 1000$ \\
\hline Asbestos testing and abatement & $\$ 2500$ \\
\hline Flooring (epoxy and sand floor) & $\$ 2400$ \\
\hline Carpentry & $\$ 1200$ \\
\hline Cabinetry and casework & $\$ 5400$ \\
\hline Electrical & $\$ 4700$ \\
\hline Painting & $\$ 2100$ \\
\hline HVAC and plumbing & $\$ 1400$ \\
\hline Autoclave & $\$ 42,600$ \\
\hline Deionized water and water softener for autoclave & $\$ 4900$ \\
\hline Water polishing system (Millipore) & $\$ 3500$ \\
\hline Glassware washer & $\$ 4200$ \\
\hline
\end{tabular}

\section{Results}

The Microbiology course has been taught six times in the renovated laboratory space, three times by Professor Michael Hanna and three times by Professor Blanca Barquera. The Biotechnology and Bioprocessing Laboratory has been taught 5 times in the renovated laboratory space. The

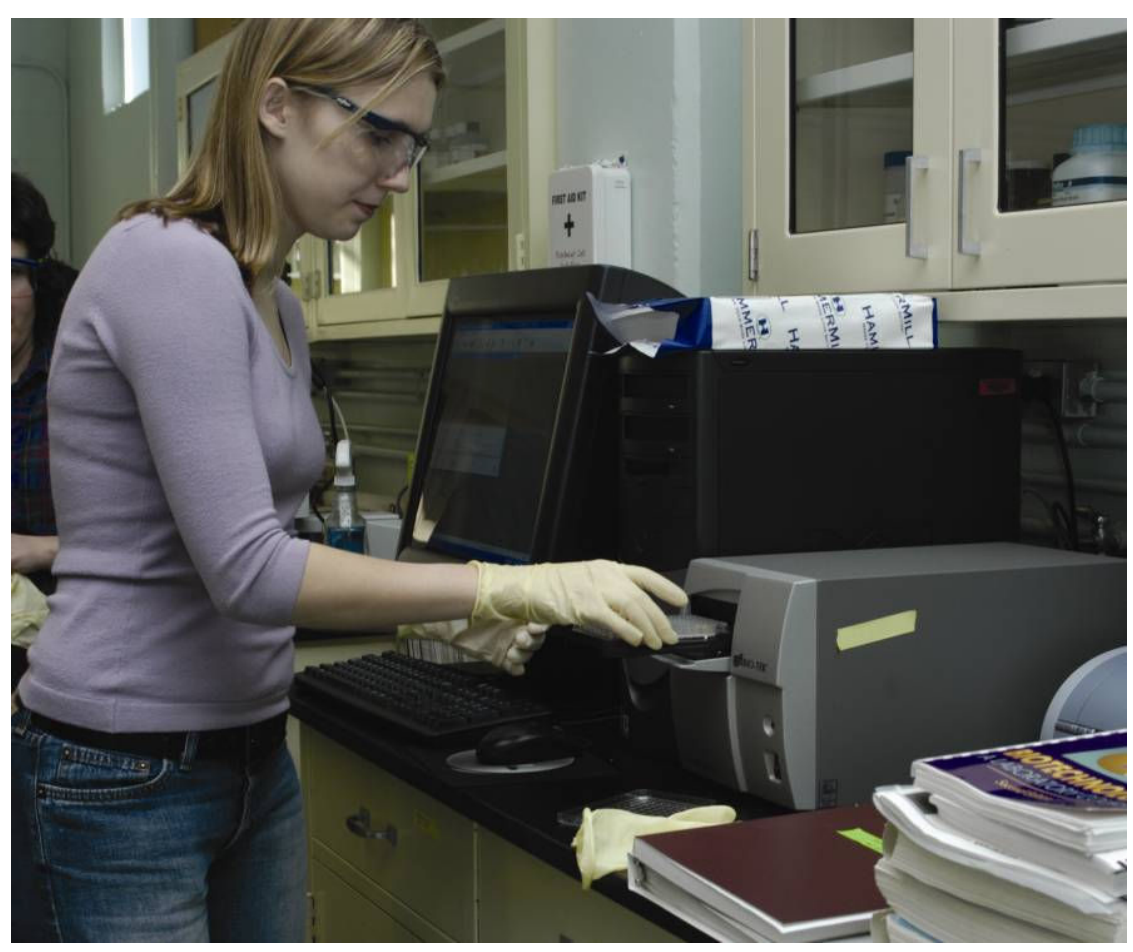

Figure 3: Student using microplate reader spectrophotometer
Biotechnology and Bioprocessing Laboratory has been consistently well received by the students. The instructional space is well designed for the course with adequate bench space. Students can be seen using the microplate reader and the microscope in Figures 3 and 4 , respectively.

A number of synergistic relationships have developed between graduate students and faculty in the Chemical and Biological Engineering Department and the Biology Department. When the instructor for the Biotechnology Laboratory was on maternity leave at the beginning of the semester, a teaching assistant from Biology helped to teach the Biotechnology laboratory course. 
When the Biology faculty and graduate students had difficulties with the bioreactors, faculty and students from Chemical and Biological Engineering provided assistance. When the equipment, particularly the gel documentation system, shakers, microscope and microplate reader, is not being used for instructional purposes, it is used for research applications by graduate students from a number of engineering and science departments. These synergistic relationships ultimately culminated in the first author requesting a joint appointment in the Department of Biology.

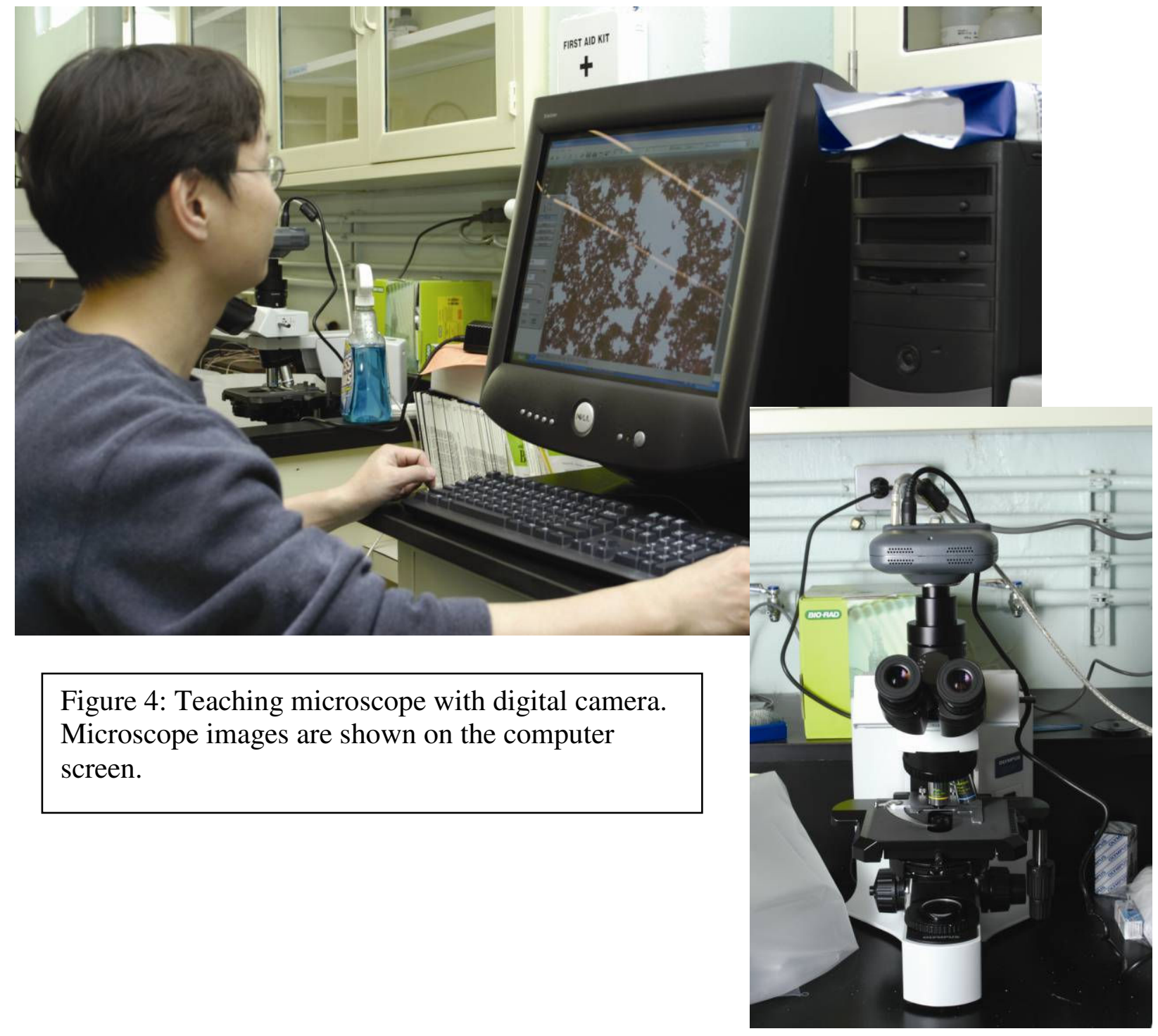

\section{Extensions of paradigm}

Rensselaer Polytechnic Institute is a medium-sized technological institute where engineering predominates. Approximately 50\% of the undergraduate students are engineers. With this strong engineering focus, it is often easier for resources to be obtained if they meet the needs of engineering students. One possible extension of this shared instructional paradigm is the development of a physiology laboratory for biology and biomedical engineering students. Currently, there is no physiology laboratory in the Biology Department and Biomedical 
Engineering students take a physiology laboratory at Albany Medical College, a nearby medical school. One idea under consideration is the development of a physiology laboratory that could be either one course taught to both groups of students or two courses sharing instructional space as in the case of the Microbiology and Biotechnology laboratories. Other possible extensions could include polymers labs used by Chemistry and Materials Science and Engineering and Chemical Engineering, nanotechnology labs shared by a variety of departments, and semiconductor processing laboratories shared by Physics, Electrical and Computer Science Engineering and Chemical Engineering.

\section{Conclusions}

The shared use of instructional facilities has been both economically and intellectually beneficial to Biology and Chemical and Biological Engineering. With the increasing costs of bringing modern research technology into the classroom, we believe that with the right outlook of the faculty and departments involved, this can serve as a model for many groups of departments to develop courses and facilities that would be prohibitively expensive for any one department. One should be aware of the number of students from each area that will utilize the laboratory. In our situation, both of the laboratories were populated by a small number of students (typically 16 or fewer per section) and the number of sections combined was three or less. Larger classes with multiple sections could experience space and timing difficulties. However, having smaller, upper level laboratory courses sharing space and equipment is a novel economy that works among collaborative individuals.

\section{Acknowledgements}

The authors would like to thank Scott Herkenham and Bob Miller of the Campus Planning and Facilities Design Department for providing mechanical drawings and project cost information.

\footnotetext{
${ }^{1}$ Copyright $@$ (1997-2008. Blackboard Inc. All rights reserved. Blackboard, the Blackboard logo, BBWorld, the Blackboard Academic Suite, the Blackboard Community System, the Blackboard Outcomes System and Behind the Blackboard are trademarks or registered trademarks of Blackboard Inc. in the United States and/or other countries. U.S. Patent No. 6,988,138.

${ }^{2}$ http://www.hhmi.org/about/index.html

3 http://www.hhmi.org/grants/institutions/

${ }^{4}$ http://www.merck.com/cr/company_profile/philanthropy_at_merck/the_merck_company_foundation/home.html
} 


\section{Appendix}

\section{Experiment 2: PCR of $\beta$-galactosidase from a plasmid vector}

\section{Each group should perform one PCR reaction}

Reading: Becker - Exercise 7 \& 8, Appendix 18; pET Directional TOPO expression kit manual (available through RPILMS (Blackboard) or http://www.invitrogen.com/content/sfs/manuals/pettopo_man.pdf ); Platinum pfx manual (available through RPILMS (Blackboard) or http://www.invitrogen.com/content/sfs/manuals/platinumpfx_pps.pdf ); Molecular Cloning Chapter 5 pgs 5.2-5.17, Chapter 8 pgs 8.2-8.41, Appendix A8 pgs A8.19-A8.24

There are a variety of ways to introduce foreign DNA into vector for production of a foreign protein. Increasingly, polymerase chain reaction (PCR) is used. PCR allows you to make virtually infinite numbers of copies of any DNA sequence with high fidelity. The amplified DNA can be constructed with a variety of adaptors allowing it to be cloned into many different vectors. In this experiment and the following ones, we will amplify the gene for $\beta$-galactosidase $\mathrm{E}$ from a plasmid, check that we have amplified the correct piece of DNA using agarose gel electrophoresis, and then insert it into an expression vector produced by Invitrogen. The insertion process uses a special kind of cloning called TOPO cloning based upon a specific enzyme present in the cloning vector. This is described in more detail in the manual. The DNA sequence that you will be amplifying is given in the appendix to this manual. Design and selection of PCR primers will be discussed in class.

Reagents and equipment

Sterile distilled water

PCR Nucleotide Mix (10 mM)

$10 \mathrm{X}$ reaction buffer

$50 \mathrm{mM} \mathrm{MgSO}_{4}$

Platinum $P f x$ DNA polymerase

Upstream and downstream primers $10 \mu \mathrm{M}$ in sterile water

Plasmid DNA containing lacZ gene $(\sim 1 \mu \mathrm{g} / \mathrm{ml})$

Micropipets

Micropipet tips

Sterile $0.5 \mathrm{ml}$ centrifuge tubes (thin wall)

Thermalcycler

1. Using micropipettes, mix the following reaction mix in a sterile $0.5 \mathrm{ml}$ centrifuge tube. Remember to always use clean pipet tips. Do not cross-contaminate the reagents. 
Sterile distilled water

10X reaction buffer

PCR nucleotide mix (10 mM each)

Upstream and downstream primer mix (10 $\mu \mathrm{M}$ each)

$\mathrm{MgSO}_{4}(50 \mathrm{mM})$

Plasmid DNA $(1 \mu \mathrm{g} / \mathrm{ml})$

Platinum $P f x$ DNA polymerase

10X PCR enhancer solution (if needed)

Total
$34.5 \mu 1$

$5 \mu 1$

$1.5 \mu 1$

$1.5 \mu 1$

$1 \mu 1$

$1 \mu 1$

$0.5 \mu 1$

$5 \mathrm{ul}$

$\mathbf{5 0} \mu \mathrm{l}$

2. The thermalcycler should be programmed to run the following program

\begin{tabular}{|l|c|c|c|}
\hline Step & Temperature & Time & Number of Cycles \\
\hline Initial Denaturation & $94^{\circ} \mathrm{C}$ & 2 minutes & 1 cycle \\
\hline Denaturation & $95^{\circ} \mathrm{C}$ & $15 \mathrm{sec}$ & \\
Annealing & $52^{\circ} \mathrm{C}^{*}$ & $30 \mathrm{sec}$ & 25 cycles \\
Extension & $68^{\circ} \mathrm{C}$ & 1 minute & \\
\hline Final extension & $68^{\circ} \mathrm{C}$ & 10 minutes & 1 cycle \\
\hline Chill & $4^{\circ} \mathrm{C}$ & Indefinite & 1 cycle \\
\hline
\end{tabular}

* The actual annealing temperature may vary depending on primer selection

3. Preheat the thermocycler to $94^{\circ} \mathrm{C}$ with lid heating before adding your samples.

4. While your samples are running you can prepare a 1.5\% agarose gel with the TA (described below) to separate your samples when they are complete.

\section{Agarose Gel Electrophoresis}

The size and purity of a DNA molecule can be assessed by agarose gel electrophoresis. DNA molecules, being negatively charged will move towards the positively charged electrode in the presence of an electric field. Their rate of movement is based on size with the largest molecules moving the slowest. By selecting the concentration of agarose in the gel, it is possible to separate molecules of various sizes. The DNA is visualized by addition of a dye, ethidium bromide, which intercalates between the bases in the DNA molecule. When exposed to UV light the ethidium bromide bound to DNA fluoresces brightly.

Note: ethidium bromide is a powerful mutagen and is moderately toxic; gloves must always be worn when working with ethidium bromide. UV light will damage skin and eyes. In addition to wearing gloves and safety glasses, do not attempt to defeat the interlock and open the observation chamber with the UV light on. 
Reagents and equipment

5X Tris-borate-EDTA (TBE) buffer

Agarose

6X Loading dye

PCR product

Electrophoresis equipment

Microwave oven

$10 \mathrm{mg} / \mathrm{ml}$ solution of ethidium bromide

$\lambda$-BstE molecular wt markers

1. The teaching assistant will prepare an appropriate size agarose gel with $1.5 \%$ (wt:volume) agarose in 0.5X TBE. Agarose is melted in the buffer in the microwave oven and allowed to cool to approx. $50^{\circ} \mathrm{C}$. Ethidium bromide is added to the gel at a concentration of $0.5 \mu \mathrm{g} / \mathrm{ml}$.

2. The gel is poured and allowed to cool until solid.

3. The TA will prepare a solution of molecular weight markers.

4. Take $5 \mu$ of your PCR product and place it in a microcentrifuge tube. Add $1 \mu$ l of the $6 \mathrm{X}$ loading dye. This serves two purposes. First, the dyes allow you to keep track of the progress of the gel. Second, the glycerol makes the samples denser than water so they will sink to the bottom of the wells.

5. Carefully load your PCR product on the gel. The TA will demonstrate the correct technique.

6. The gel will be run at $3-5 \mathrm{~V} / \mathrm{cm}$ for the next hour. You can come back later or check the website to see the results. Make sure you note the approximate molecular weight of your PCR product. 


\section{Experiment 5: Bacterial Transformation and Expression}

Reading: Becker -Exercise 3 and 15, Handout on YSI analyzer

\section{You will need to come in on Tuesday to do the transformation and then briefly on Wednesday morning to start your growth and expression experiment}

Each group should prepare transform one plasmid into a vial of competent cells.

After you have verified that you made the construct containing our gene of interest, you will transform them into a different strain of E. coli which is capable of expressing your gene. These cells have been provided in a competent state (that is capable of taking up foreign DNA).Your gene has been placed under the control of the lac promoter. In order to induce expression, we will add isopropyl $\beta$-D-thiogalactoside (IPTG) once the cells have reached a desired density. IPTG is an analog of lactose.

\section{Transformation of BL21 Star cells}

Reagents and equipment

Plasmid DNA from last time

BL21 Star (DE3) One Shot cells

LB with $50 \mu \mathrm{g} / \mathrm{ml}$ of ampicillin and $5 \mathrm{~g} / \mathrm{L}$ glucose

SOC medium (warmed to room temperature)

$37^{\circ} \mathrm{C}$ incubators (shaking and nonshaking)

$42{ }^{\circ} \mathrm{C}$ water bath

Sterile culture tubes

Ice

Micropipets

Sterile micropipet tips

Sterile microcentrifuge tubes

1. Thaw on ice, one vial of BL21 Star (DE3) One Shot cells

2. Add 1-5 $\mu \mathrm{l}$ of the plasmid DNA (containing 5-10 ng of DNA, dilute with TE as needed) to the vial of BL21 Star cells mix gently by stirring with the pipet tip. Do not mix by pipetting up and down.

3. Incubate on ice for 30 minutes

4. Heat-shock the cells by placing in the $42{ }^{\circ} \mathrm{C}$ water bath for 30 seconds without shaking.

5. Immediately transfer the tubes to ice.

6. Add $250 \mu \mathrm{L}$ of room temperature SOC medium.

7. Cap the tubes tightly and shake the tube horizontally $(200 \mathrm{rpm})$ at $37^{\circ} \mathrm{C}$ for 30 minutes.

8. Add the entire transformation reaction to $10 \mathrm{ml}$ of $\mathrm{LB}$ with ampicillin and glucose

9. Grow overnight at $37^{\circ} \mathrm{C}$ with shaking

\section{Growth and expression kinetics}

Now that you have created the microorganism strain that we will do our production in, it's time to explore its growth behavior in culture. The bacteria will be grown in a rich medium consisting of LB plus $10 \mathrm{~g} / \mathrm{l}$ of glucose and $50 \mu \mathrm{g} / \mathrm{ml}$ of ampicillin to maintain the plasmid. Glucose and LB 
cannot be sterilized together since the glucose will caramelize in the presence of salts. The glucose must be added aseptically after sterilization. Ampicillin is heat labile so it must be filter sterilized.

In this experiment you will monitor the growth of the bacteria, their glucose uptake and their acetate production. You will also assay for production of $\beta$-galactosidase with and without stimulation with isopropyl $\beta$-D-thiogalactopyranoside (IPTG). To assay for $\beta$-galactosidase we will use another synthetic analog of lactose, o-nitrophenyl $\beta$-D-galactopyranoside (ONPG). When ONPG is hydrolyzed by $\beta$-galactosidase it releases nitrophenol which has a yellow color. Hence the amount of $\beta$-galactosidase can be measured by its activity in hydrolyzing ONPG which can be detected by the evolution of the yellow color.

This experiment consists of three assays. Two will be done more or less simultaneously in a 96well plate, growth and $\beta$-galactosidase activity. Glucose concentrations will be measured using the YSI analyzer. The overall sampling and analysis is as follows.

1. Take a sample.

2. Measure the optical density of an aliquot and place the remaining sample on ice.

3. Transfer an aliquot to the buffer for $\beta$-galactosidase assay and begin the cell lysis.

4. Centrifuge the remaining sample and transfer the supernatent to a clean tube.

5. When sampling is completed perform the glucose assays, followed by the $\beta$-galactosidase assay.

\section{Part 1: Growth kinetics}

Reagents and equipment

$10 \mathrm{ml}$ of overnight culture of E. coli

$100 \mathrm{ml} \mathrm{LB}$ medium (with $5 \mathrm{~g} / \mathrm{L}$ glucose, $50 \mu \mathrm{g} / \mathrm{ml}$ ampicillin)

$100 \mathrm{mM}$ IPTG

shaker

microcentrifuge tubes

96-well microplate

spectrophotometer

micropipet

micropipet tips

sterile pipets

pipet bulbs

ice

$\mathrm{pH}$ indicator paper

1. Remove a 1-ml sample of the culture medium before inoculation to serve as a control for all the assays.

2. Two hours before the lab is scheduled to start, inoculate $100 \mathrm{ml}$ of LB medium (with 5 $\mathrm{g} / \mathrm{L}$ glucose) with $5 \mathrm{ml}\left(5 \%\right.$ inoculum) overnight culture of $E$. coli. Grow the cells at $37^{\circ} \mathrm{C}$ at $\sim 250 \mathrm{rpm}$ in a shaker. Make sure you use the $37^{\circ} \mathrm{C}$ warm room, not the $30^{\circ} \mathrm{C}$ room!! Store the remaining $5 \mathrm{ml}$ of culture at $4{ }^{\circ} \mathrm{C}$ to use as an inoculum for your fermentor culture. 
3. When you come into lab, withdraw a $1 \mathrm{ml}$ of sample every 20-30 minutes using sterile micropipet tips and place into a microcentrifuge tube.

4. Determine the cell density of the samples by measuring the optical density at of $200 \mu \mathrm{l}$ of sample at $600 \mathrm{~nm}$. Use $200 \mu \mathrm{l}$ of the LB you took before inoculation as the blank. (Use wells A1-A8 for these measurements.) Dilute the samples with LB if the OD value is above 0.8.

5. Measure the $\mathrm{pH}$ of the culture using the $\mathrm{pH}$ paper.

6. Centrifuge the sample in the microcentrifuge. Separate the supernatant from the pellet and store both on ice. The supernatant will be used for the glucose assay and the pellet for the $\beta$ galactosidase assay as described in Parts 2 and 3.

7. When the OD reaches between 0.3 and 0.5 , split the culture in half (into two shake flasks) and add IPTG one half to a final concentration of $1 \mathrm{mM}$ (for induction). Place both flasks back into the shaker and take samples as described above every 30 minutes for the next 1.5 to 2 hours.

Part 2: Assay for $\beta$-galactosidase activity

Reagents and equipment

samples from Part 1

lysis buffer (50 mM Tris-HCl, pH 8.0, 1 mM EDTA, $3 \mathrm{mg} / \mathrm{ml}$ lysozyme)

assay buffer (100 mM sodium phosphate (pH 7.5), $10 \mathrm{mM} \mathrm{KCl,} 1 \mathrm{mM} \mathrm{MgSO}_{4}, 50 \mathrm{mM} \beta$ mercaptoethanol)

1 96-well microplate

ONPG (4 mg/mL in $100 \mathrm{mM}$ sodium phosphate $\mathrm{pH} 7.5)$

micropipet

micropipet tips

multichannel pipette

$37^{\circ} \mathrm{C}$ incubator

1. Centrifuge the remaining sample $(\sim 800 \mu \mathrm{L})$. Save the supernatant for part 3

2. Resuspend the cell pellet in $100 \mu \mathrm{L}$ of lysis buffer by vortexing.

3. Incubate on ice for 30 minutes.

4. Freeze-thaw cycle the cells by placing them in a dry ice/ethanol bath and then warm water $\left(\sim 37^{\circ} \mathrm{C}\right) 5$ times.

5. Centrifuge 5 minutes at maximum speed in a microcentrifuge. Remove the supernatant to a clean tube and label.

6. Repeat the above procedure for each sample.

7. After the last sample has been lysed, place $100 \mu \mathrm{L}$ of assay buffer in enough microplate wells for each sample plus one blank. Add $20 \mu \mathrm{L}$ of cell extract to each well (from each different sample). For the blank, add $20 \mu \mathrm{L}$ of lysis buffer.

8. Start the reaction by adding $50 \mu \mathrm{l}$ of ONPG to all the wells using a multichannel pipet. Heat the microplate reader to $37{ }^{\circ} \mathrm{C}$. Read the plate in kinetic mode at $420 \mathrm{~nm}$. The program records the kinetic data and gives the slope of O.D Vs Time, which is the rate of the reaction. 
The number of units of $\beta$-galactosidase for each of the samples can be calculated by the formula:

$$
\begin{aligned}
& \text { Units }=\text { Reaction rate } /(\text { Volume } \mathrm{x} \text { OD600) } \\
& \text { where Volume }=\text { Volume of culture used in the assay }(\mathrm{ml})
\end{aligned}
$$

Hence, you can calculate the $\beta$-galactosidase activity as a function of time throughout the culture.

\section{Part 3: Analysis of glucose consumption}

Reagents and equipment

samples from Part 2

YSI analyzer

1. Take the supernatant from part 2 .

2. The TA will demonstrate the use of the YSI analyzer. It will give you the concentrations of glucose in your samples

3. Draw a graph of glucose concentration vs. Time (hrs) and discuss the glucose uptake profile. 